\title{
An Etymological Study of Mythical Lakes in Iranian Bundahišn
}

\author{
Hossein Najari (Corresponding author) \\ Shiraz University, Eram Square, Shiraz, Iran \\ E-mail: najari@shirazu.ac.ir \\ Zahra Mahjoub \\ Shiraz University, Shiraz, Iran \\ E-mail: z.mahjoub@hotmail.com
}

Doi:10.7575/aiac.alls.v.6n.6p.174

Received: 30/07/2015

URL: http://dx.doi.org/10.7575/aiac.alls.v.6n.6p.174

Accepted: 02/10/2015

\begin{abstract}
One of the myth-making phenomena is lake, which has often a counterpart in reality. Regarding the possible limits of mythological lakes of Iranian Bundahišn, sometimes their place can be found in natural geography. Iranian Bundahišn, as one of the great works of Middle Persian (Pahlavi) language, contains a large number of mythological geography names. This paper focuses on the mythical lakes of Iranian Bundahišn. Some of the mythical lakes are nominally comparable to the present lakes, but are geographically located in different places. Yet, in the present research attempt is made to match the mythical lakes of Iranian Bundahišn with natural lakes. Furthermore, they are studied in the light of etymological and mythological principles. The study indicates that mythical lakes are often both located in south and along the "Frāxkard Sea" and sometimes they correspond with the natural geography, according to the existing mythological points and current characteristics of the lakes.
\end{abstract}

Keywords: mythological geography, Bundahišn, lake, Iranian studies, Middle Persian

\section{Introduction}

Discovering the geographical location of mythical places in our present-day world is one of the most noteworthy matters for mythologists. As the setting of a myth bears an unrealistic geography, in myths a place is the reflection of typical forms of myths which come into being in imaginary and unrealistic places (Vaheddoost 1379AH/2000: 369). However, it is impossible to find an exact conformity between natural geography and mythical geography or to precisely locate the place of an unreal within the real world (Mokhtari 1379AH/2000: 99). In Pahlavi literary works it has been mentioned about mythical geography, among which Bundahišn $n^{l}$ is replete with names fluctuating between mythical and natural geographies; consequently, it is believed that no exact match occurs between mythical and natural geographies. Conversely, there is another idea according to which mythical geography has root in natural geography, so it can be traced to the reality. The present research is an attempt to find the possible conformity between natural geography and mythical geography of lakes in Iranian Bundahišn.

Myth in Bundahišn is linked with Creation (Genesis) that begins with a drop of "water", by virtue of Islamic and Jewish sources "water" is the substance of Creation (Mirfakhraie 1366AH/1987: 194). Being an indication of immensity of the nature and taking a dominant position in myths, water is the second physical creature of Ūrmazd (Bahar 1387AH/2000: 45). At the outset of creation, the land was dry and no sign of water could be seen, then Tištar ${ }^{2}$ fashioned clouds, by the wind departed them to the sky, thus rain started and continued thirty days, so water covered all the Earth and rose up to the height of a man. Afterwards, the wind spread all that water and directed it to the boundary of the Earth, from which "Farāxkard" Sea, three major seas, thirty minor seas, and two lakes originated (Gholizadeh 1387AH/2008: 23). Farāxkard Sea, the vastest sea, covers one third of the Earth`s surface and its water is the most desirable and superior in comparison with others because of its warmth and purity. Inside this vast sea there exist one thousand seas called “čašmagān Ardwīsūr" or "Xānīgān sea" (Tafazzoli 2001: 201). Any sea has an aquifer into which enters water and runs to the sea, length and width of each aquifer and sea is equal to forty days horse-riding or 16oo Farsang ${ }^{3}$. Everyday water streams from čašmagān Ardwīsūr to the south (Gholizadeh 1387AH/2008: 181). In religion, čašmagān Ardwīsūr are named "Sea-Source" because ,similar to the eyes of men, they are sources of waters, and are called "lake" too, such as

\footnotetext{
${ }^{1}$ The greatest historical-religious work written in Pahlavi language, its original name might be "Zand- āgāhīh" meaning "information based on Zand". The name reveals that it has been the main source for translations and interpretations of Avesta. It is well-known because of its chapters related to "Creation" (Tafazzoli 1386AH/ 2006: 143).

${ }^{2}$ Great angel of rain.

${ }^{3}$ Each Farsang equals $6240 \mathrm{~m}$
} 
Čēčast Lake, Sōwar Lake, Xwārazm Lake, Frazdān Lake, Zarrēnōmand Lake, Astwāst Lake, Husraw Lake, Sadwēs Lake, and Urwēs Lake (Bahar 1390AH/2011: 77).

Lakes as myth-making phenomena of the nature own a special position in Pahlavi and Avestan scripts. As a result, a large number of Iranian mythologists like to get acquainted with these natural phenomena. Nevertheless, a small number of studies done on this area, among which Bahar's research (1362AH/1983) is more detailed and coherent. However, there are still many things to understand about the mythological lakes and they need a deeper insight in this field. One of the most interesting issues is to offer a description based on etymological study of mythical lakes in Iranian Bundahišn to think through the subject matter comprehensively. The current research seeks to investigate whether there is any conformity between mythological lakes and natural lakes. Due to the objectives of the study, any lake is surveyed individually and etymological and mythical outcomes about each lake are cited separately. Moreover, the position of lakes in mythology and geography is defined.

\section{Review of literature}

As is apparent from the title, this research focuses on the geography of Iranian Bundahishn. Foreign scholars who have enormous interest in this area, have done considerable amount of investigation on the mythical and historical geography of Iran and central Asia, a great number of which have been examined and used in this study which we will now allude to. Kiepert and McMillan (1881) has done a research on ancient world geography. Modi (1889) has examined ancient geography of Persia based on the Pahlavi book of Shahrestanhaye Iran. A paper has been presented by Le Strange concerning the historical geography of Islamic countries, whose Persian translation is based on the second English edition of the work which is a condensed review of the research and writings done by old Muslim geographers. Benveniste (1939) has described Aryan territories and regions such as Kharezm, Sogdiana etc. in a paper including a list of its various geographical features. Marquart (1947) has studied and investigated many geographical areas close to the mythical river of Veh Rood and Arang. The geographical and climatic conditions of Haroiva with regard to Manichean texts has been taken into consideration by Henning in 1947. Another research been done by Whitehouse in 1970 which is a survey on the monuments, geographical location and transaction conditions of the port of Siraf. Brunner (1986) studied the etymology and the features of the mythical Arang River, linking them to the field of natural geography. In 1987, Gnoli inspected the customs and the geographical location of the east of Iran from the past up to the present, in addition to examining the geography of Avesta. Hewsen (1987) studied the mythical lakes, Hrazdan and Frazdan, and characterized and compared the two. The geography of Balkh throughout history was probed by Balland in 1988. Planhol, in 1990 studied the historical geography of the Caspian Sea and the raids of different tribes happening around the area. Schmitt has also done a significant research in 1990 which is about the areas near the Black sea and how the invasion of different folks to these areas caused the Black sea to have many dissimilar names. In 1993, Gnoli investigated the mythical river of Dāiti. He has also done a research regarding Hamun Lake in literature and mythology in 2003. Sarkhosh Curtis and Stewart carried out their research on the emergence of the Persian Emperor and Avestan geography, taking into account the mythical geography in their studies as well. Cereti (2007) studied the 10th and 12th chapters of "Bundahišn". An investigation was done by Panaino (2013) into the geographical location and the etymology of Kayanse in mythology, along with description of the events taking place in the vicinity of this lake in the Apocalypse and at the time of Zoroaster. Gharashi $(1380 \mathrm{H} / 2001)$ has dug into Indo-Iranian mythology, as well as the geography of its ancient or mythological mountains, seas, rivers, and lakes.

\section{List of the mythical lakes in Bundahišn}

\subsection{Astwāst Lake}

This lake possesses pure water unremittingly flowing into seas. Its water is so bright and glorious that one may not distinguish it from sunshine. It is used to adorn dead bodies appropriately in Frašegird. In Bundahišn and Vendidad, the name of this lake is mentioned besides Frazdān Lake, Zarrēnōmand Lake, Husraw Lake and Sadwēs Lake; although, their location remains unsaid (Gholizadeh 1387AH/2008: 80). Its location is supposed to be in the south of Iran, probably in Sistan, because aforementioned lakes are assumed to be there. Although its name is not mentioned in Avesta, in Zamyād Yašt a mountain named Adutauuås(ca) ${ }^{4}$ is cited that its name is so similar to this lake.

According to Iranian Bundahišn:

- ' "war ì Astwāst rāy paydāg kū āb ̄̄ a-winast ast andar zrēhīhā hāmwār hamē tazēd” (Pakzad 1384AH/2005: $165)$.

- " "it is apparent that Astwāst Lake owns a pure water unremittingly running into seas" (Bahar 1390AH/2011: 77).

Astwāst $\rightarrow$ probably its old form was a $+\sqrt{ }$ staw $+\sqrt{a} \mathrm{~s}+$ ta-, according to which it is a composition of Avestan and Parthian languages, and is apparently an adjective used as a proper noun.

a-: this is perhaps from Avestan employed as prefix of verb (Reichelt 1911: 221). staw- : present stem originated from Old Iranian root staw-, Sanskrit root stu- (Mayrhofer 1996: 757) derived from Indo-European root steu- "to praise

\footnotetext{
${ }^{4}$ It means "full of flowing waters" (Humbach 1998: 77); in addition, it is translated as "(a mountain) dominating waters" (Pourdavoud 1377AH/1998, vol.2: 329). It is probably derived from stem A $\delta$ utauuah- and suffix ca- meaning "also". Change of $\delta$ in Avesta into s in Middle Persian can be seen in Urwēs too. Adutauuah- is probably composed of

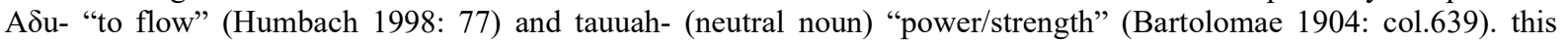
word is derived from Old Iranian root tu " to be able" (Mansoori 1384AH/2005: 420)
} 
loudly" (Pokorny 2007: 2966), Avestan root stu- "to praise" (Bartholomae 1904: col.1593). ās- ${ }^{5}$ is the present stem of āsīdan infinitive that means " to rise (sun)", this word is Parthian and is derived from Old Iranian â-, ṇsa- (Hassandoost 1383AH/2004: 28) is derived from Sanskrit root naś- " to reach" (Mayrhofer 1996: 27), Avestan root nas- " to reach" (Bartholomae 1904: col.1055). ta- adjective suffix (Jackson 1968, p.219). Ultimately, considering purity of water and its holiness in Frašegird and also in line with the aforesaid analysis, one may come to the concept of "praising glitter" for the word.

\subsection{Urwēs $^{6}$ Lake}

According to Bundahišn, Urwēs Lake is at the top of Hugar Mountain, and Splendor of God (Farrah-ī Izadi) at dawn comes to Urwēs Lake and Spentä Mainyu receives it (Bahar 1390AH/2011: 114). Some mythologists believe that this river is a split of Hāmun Lake. However, Humbach and Vogelsong presumably estimate the route of the river to be between Sistan and Herat, where Ghaznī River joins Arghandab through "Āb İstade" and "Lora River" (Sarkhosh Curtis- Stewart 2005: 40)

As stated in Iranian Bundahišn:

- "war ī Urwēs pad Hugar ī buland" (Pakzad 1384AH/2005: 166).

- "Urwēs Lake is at the top of Huger" (Bahar 1390AH/2011: 77).

Urwēs $\rightarrow$ a proper name, equivalent to Avestan uruuajā- (feminine noun) (Bartholomae 1904: col.1537); derived from Sanskrit root vreś- "to whirl" (Mayrhofer 1996: 598); derived from Indo-European root ųreiḱ "to rotate" (Pokorny 2007: 3352). Avestan root uruuaēs- "to turn" (Bartholomae 1904: col.1533). The literal meaning of this lake is "whirlpool" or "having a spiral route", probably at the top has a spiral route (Meyers \& O'conner 1983: 629).

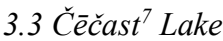

Čěčast is a mythical lake in the east of Iran compared with "Ūrmia Lake" today (Cereti 2007: 56), birthplace of Zoroaster based on an account. It is said that length and width of Čěčast is four Farsang. According to Zādspram, Čēčast gained a particular holiness due to Azargoshasb during Sassanid era (Tafazzoli 1990: 107). It is narrated that Azargoshasp has been formerly near a city in Azerbaijan called Ganzak, then around $5^{\text {th }}$ century Azargoshasp was moved from Ganzak to Takht-e Soleymān and since that time Zoroastrian priests (Mobad) communicated with Čečast (Boyce 2000: 289). There is an account according to which in Kai Khosrow era near this mythical lake placed an Idol Temple, for some reason was ruined by his order and Azargoshasb Fire Temple was constructed in its place (Pourdavoud 1377AH/1998, vol.1: 213).

According to Iranian Bundahišn:

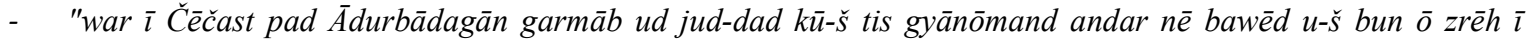
Frāxkard paywast ēstēd" (pakzad 1384AH/2005: 163).

- " "Čēčast Lake is in Azerbaijan, a salty dead water holds no living creature, its root joins Farāxkard” (Bahar 1390AH/2011: 77).

Čěčast $^{8} \rightarrow$ a proper noun, its Avestan equivalent is čaěčasta- (masculine noun) (Bartholomae 1904: col.575). Its decomposed form may be čā + čas + ta- ; seemingly an adjective used as a proper noun here.

čaē- : perhaps a verb root, derived from Old Iranian root kai- (čai) “ to move/flow” (Cheung 2007: 229); derived from Indo-European root kēi- "to move" (Pokorny 2007: 1571). čas- probably present stem derived from Old Iranian kas-a. Old Iranian root kas- "to appear" (Mansoori 1384AH/2005: 225), derived from Sanskrit root kāś- (Mayrhofer 1996: 346). Avestan root kas- means "to see" (Bartholomae 1904: col.459). -ta is an adjective suffix (Jackson 1968: 219). Overall, the concept of "showy flow" may be understood from the name of the lake.

\subsection{Husraw Lake}

Husraw $^{9}$ Lake is located in Azerbaijan near Old Fire of Husraw i.e. Azargoshasp Fire Temple. Some believe it is near Čēčast Lake. Also, In Avesta its name is mentioned. It is narrated in Zamyād Yašt that Afrāsīāb went down in Farāxkard Sea three times to obtain the Farrah, each time a Lake split from Farāxkard, first time Husraw Lake, second

\footnotetext{
${ }^{5}$ It is also believed to be derived from Avestan root san "to ascend/rise" (Cheung 2007: 330).

${ }^{6}$ Also Urwēš, runs to Kiyanse Sea, as it is supposes to be equal with Hāmun Lake, Urwēs might be another name for "Hirmand" (Gholizadeh 1387AH/2008: 101). In Avesta a river entitled as uruuadā- (Humbach 1998: 142), and in Zamyād Yaøt this river is called as "having a lot of pasture" (ibid.49).

${ }^{7}$ Čaěčasta- is supposed to mean "glowing brightness" (Bartolomae 1904: col.575), some equate "Kabudan" sea with Čēčast Lake and say "glowing brightness" is not appropriate for it. It is believed that plenty of salt made it glow and is purple because of its salts (Houtsma 1993: 1037), and is used for its salts to cure illnesses (Behzadi 1368AH/1989: 267). The word Xonjast is mentioned in Shahnameh to refer to the sea in which Afrāsiāb got concealed (pourdavoud 1377AH/1998, vol.1: 213). In past, this lake was also called "Armaniye”, "Shahi”,"Tala"," Shur Darya”( salt sea), and "Rezaiye"( Gholizadeh 1387AH/2008: 183). Some sources equal this lake with Farakhkard (Tafazzoli 1990: 107). Nyberg assumes that it is the same with šěčikān (Nyberg 1974: 186). This lake is also called Garmab "having warm water", in Avesta it is described as "deep and vast" (Boyce 2000: 289).

${ }^{8}$ Also Čěčist in Middle Persian (Nyberg 1974: 54)

${ }^{9}$ Some believe it is probably Van or Swan (Oshidari 1398AH/2010: 400).
} 
time vańhazdā, third time aßždānuua (Humbach 1998: 46). In other words, Husraw Lake is made of the water came from Farāxkard (Gholizadeh 1387AH/2008: 336).

According to Iranian Bundahišn:

- "war ì Husraw pad čahār frasang ō Čēčast" (Pakzad 1384AH/2005: 165).

- "Husraw Lake is four Farsang far from Čéčast” ( Bahar 1390AH/2011: 77).

Husraw $^{10} \rightarrow$ a proper name composed of $\mathrm{hu}^{11}+$ sraw.

sraw $^{12}$ : a noun, equivalent to Old Iranian sarawah- " speech” (Mansoori 1384AH/2005: 383), Avestan srauuah- , a noun “speech/word”; (Bartholomae 1904: col.1643), Middle Persian sraw "word/charm” (Mackenzie 1388AH/2009: 137), Modern Persian sorw!, sorowd (Mo'in 1375AH/1996, vol.2: 1877).In total, it means "good fame” (Humbach 1998: 137).

3.5 Xwārazm ${ }^{13}$ Lake

It is recounted this lake gives advantage and pleasure (Cereti 2007: 59). The location of Xwārazm Lake or Xive $\mathrm{H}_{1}$ liye is supposed to be in a cold region at the west of Turkestan and south of Kazakhstan. Its features are being vast and holding blue water with a little salt. In Avesta and Behistun Inscription, only the name of Xwārazm Land is stated, where is at low height and this lowness increases in the lake area (Rapoport 1991: 511). Ibn-e Roste is the first Arab geographer pointing to this lake as "Bohayre Xwārazm". "Russian Sea" was its next name and was known as "Blue Sea" as well (Spuler 1986: 250).Some equate it with "Aral Lake" (Cereti 2007: 59).

According to Iranian Bundahišn:

- "war ̄ Xwārazm rāy gōwēd kū awiš be dād ēstēd Ahrišwang $\bar{l}$ xwāstag ud tuwāngarīh ud xwābrīh ud abāyišnīgīh ud hu-rāmīh" (Pakzad 1384AH/2005: 164).

- " "it is uttered about Xwārazm Lake that Ahrišwang has given it authority, delight, competency and liveliness" (Bahar 1390AH/2011: 77).

Xwārazm ${ }^{14} \rightarrow$ a proper noun, equivalent to Old Persian hUvārazmī- [ [ ${ }^{\mathrm{h}}$ " "good" + vāra "?” + zmī "land" ]( Kent 1953: 177) and Avestan $x^{v}$ āirizam- (feminine noun) (Bartholomae 1904: col.1878). This word is probably composed of xwār ${ }^{15}$ $+\mathrm{a}+\mathrm{zm}$.

xwār: adjective, derived from Old Iranian form xwa- ā9ra- (Mansoori 1384AH/2005: 513), Sogdian xwỷr (xuyār-) “ mean , easy, light, low" (Gharib 1383AH/2004: 440), Middle Persian xwār- " light, easy, mean, low” (Mackenzie 1388AH/2009: 165), and Modern Persian xār (Mo'in 1375AH/1996, vol.1: 1447). a- is an infix kept from Old Iranian in the form xwāra- in this word. zm, a noun equivalent to Avestan zam- ( feminine noun) (Bartholomae 1904: 1662). Ashkanid Pahlavi zmyg (zamīg) (Boyce 1977: 104). Middle Persian zamīg "land" (Mackenzie 1388AH/2009: 169). Modern Persian zami, zamin "land" (Mo'in 1375AH/1996, vol.2: 1747). Although there are different denomination reasons for Xwārazm, the author believes the concept "low land" is appropriate because Xwārazm Lake is situated in an area that is low at height.

\subsection{Zarrēnōmand Lake}

Perhaps in the past, there existed a lake in Hamadan and Saveh region called Zarmand ${ }^{16}$, today the area called Zarand of Saveh ${ }^{17}$ may be resulted from that name. In Xwarshed Nyāyesh also Zarrēnōmand is cited as a lake or pool that means

10 Avestan equivalent hu-sravah- (Mansoori 1384AH/2005: 383), Sanskrit su- śravas- (Mayrhofer 1996: 784), Avestan hoasrauunah- (masculine noun) (Bartolome 1904: col.1738), Pazand xusrūb (Nyberg 1974: 104), Ashkanid Pahlavi hwsrwg (husrōg) "famous/renowned" (Boyce 1977: 49), Middle Persian Husraw "well-known" (Mackenzie 1388AH/2009: 91), and Modern Persian Xosrow (Khalaf-e Tabrizi 1361AH/1982, vol.2.: 748).

${ }^{11} \mathrm{Hu}-$ : prefix, Avestan equivalent hu- hū- (adverb or noun prefix) (Reichelt 1911: 278), and Sanskrit sū- "good" (Mayrhofer 1996: 734).

${ }^{12}$ Derived from Old Iranian sraw- "to listen/call” (Mansoori 1384AH/2005: 383). Sanskrit root s'rav- (Mayrhofer 1996: 666). Avetan root sru- "to listen" (Bartolome 1904: col.1643).

${ }^{13}$ Except Bundahišn, the name of this lake is mentioned in no Pahlavi script (Cereti 2007: 59).

${ }^{14}$ It is read as $X^{u}$ ārizm (Nyberg 1974: 221). There are 3 hypothesizes about the concept of this word: 1) Hollow land 2) Sun land 3) Easy war. it is related in Shahnameh that Kai Khosrow attacked Afrāsiāâ to take his father's revenge. Shideh the commander of Turan's Army fought with Kai Khosrow and lost, then Kai Khosrow seized Xwārazm, this is the reason of calling it "easy war" (Khosrobeigi 1368AH/1989: 75), its equivalent in Pazand razm "war" (Nyberg 1974: 169), Ashkanid Pahlavi rzm(razm) (Boyce 1977: 80).

${ }^{15}$ Also used to mean "sun", Avestan huuar- "sun" (neutral noun) (Bartolomae 1904: col.1874). Soghdian xwyr (xuwer, xoyr) "sun” (Gharib 1383AH/2004: 441). Ashkanid Pahlavi xwr (xwār) (Boyce 1977: 101), Middle Persian xwār "sun”" (Mackenzie 1388AH/2009: 165).

${ }^{16}$ Some take it as Zāyandé-Rūd of Isfahan, and some as Zarmand river of Sistan (Pourdavoud 1347AH/1998, vol.2: 345). Perhaps it is zarənumaitī- in Zamyād Yasht (Bartolomae 1904: col.1683), zarənumaitī is a river like Arghandab that joins Helmand River and flows to Kiyanse Sea, for this reason Helmand in Bundahisn is called Zarrēnōmand (Gnoli 2003: 171).

${ }^{17}$ The meaning of Saveh in most dictionaries is indicated as "gold dust", related to zarənumaitī and Zarrēnōmand. 
"having gold". The water of Zarmand points to water in which dust of gold is solved and is used for Judgment of İzad (God) (Razi 1385AH/2006: 306).

"war ̄̄ Zarrēnōmand pad Hamadān" (Pakzad 1384AH/2005: 165).

“Zarrēnōmand Lake is in Hamadan" (Bahar 1390AH/2011: 77).

Zarrēnōmand ${ }^{18} \rightarrow$ the primary form of this word might be zarr- + -ēn- + -ōmand.

Zarrēn ${ }^{19}$ : A attributive adjective functioning as a noun, derived from Avestan zarənaēna- "gold" (Bartholomae 1904: col.1683), Sogdian zyrnynyy (zirnēnē) "golden" (Gharib 1383AH/2004: 472), Pazand zarrīn (Nyberg 1974: 230), Ashkanid Pahlavi zarnyn (zarnēn) (Boyce 1977: 105), Middle Persian zarrēn (Mackenzie 1388AH/2009: 170), and Modern Persian zarrin (Mo'in 1375AH/1996: 1738). -ōmand possessive adjective suffix "to have/ hold" adding to a noun (Abolghasemi 1377AH/1998: 69). Based on aforementioned discussions the concept of the lake name is "having gold".

3.7 Sadwēs ${ }^{20}$ Lake

In accordance with the Selections of Zādspram, Sadwēs is a lake close to Farāxkard Sea that pushes back impurities and filths from the salty sea in order to let what is bright and pure enter Farāxkard and čašmagān Ardwīsūr (Rashedmohassel 1385AH/2006: 43); moreover, band of Sadwēs Lake is fastened to Sadwēs Star that guards seas and regions of the south (Afifi 1374AH/1995: 557) and is called Lord of Depth too (Bahar 1390AH/2011: 89), this is perhaps why the tide is related to it. Based upon Bundahišn, two winds blow from the front of the Moon and their place is in Sadwēs Lake, one is known as the pusher and the other as the puller. Tiding happens when the puller blows and sinking takes place as soon as the pusher blows (ibid. 74). Some introduce this lake as Sadwēs Gulf which is found between Farāxkard Sea and Pūīdīg (Max Müller 1880: 87), since Farāxkard is in the south and alongside Alborz, Sadwēs must be in this area as well (Rashedmohassel 1385AH/2006: 43). Cereti links Sadwēs ${ }^{21}$ with Strait of Hormuz and Oman Sea (Cereti 2007: 55). The author believes that the lake is probably placed at the south, because relying on the myth this lake is neighboring Farāxkard and Farāxkard itself is situated in the south as discussed previously.

According to Iranian Bundahišn:

- "mayān ì èn zrēh ì Frāxkard ud ān ì Pūìdīg pahlūg zrēh dārēd kē war ì Sadwēs xwānēnd" (Pakzad 1384AH/2005: 142).

- "Between this Farāxkard Sea and alongside that Pūì̄ig there is a sea called Sadwēs Lake" (Bahar 1390AH/2011: 73).

Sadwēs $\rightarrow$ a proper noun, probably composed of two parts: $\operatorname{sad}^{22}+$ wēs

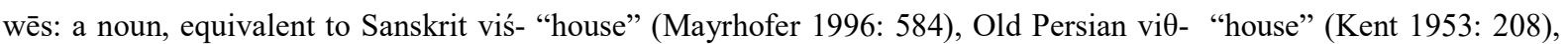
Ashkanid Pahlavi wys (wis) "village" (Boyce 1977: 97),Middle Persian vis- " village" (Mackenzie 1388AH/2009: 137); derived from Sanskrit root veś- " to dwell/arrive" (Mayrhofer 1996: 584), and Avestan root vis- "to serve" (Bartholomae 1904: col.1314). In general, it might mean "having hundred servants" or "having hundred houses".

3.8 Sōwar ${ }^{23}$ Lake

About creation of this lake it is related that after Ahriman's attack to the water and water's defense several lakes came into being, one of them was Sōwar. Sōwar pushes away any dirtiness and remains pure and bright, and it is so profound that if something falls into it never reaches the end of the lake. Āzar Barzin Mehr had been initially placed on the beach of this lake, that's why it was called Āzar Sudi Mehr or Mehr Sud. Since Āzar Barzin Mehr's building had been in Rivand Mountain near Nishapur, therefore the location of this lake must be at Khorasan (Gholizadeh 1387AH/2008: 280). It is also supposed that Sōwar Lake is situated in Abar-Šahr from which luxury, bounty; joy, honor, and liberty are originated. Monshizade relates it with "Sabz or Sowz Spring" in the north east of Nishapur placed at Binālud Mountain (Cereti 2007: 56). Sabz Spring is mentioned as Sow Spring in Shahnameh (Salem 1383AH/2004: 149).

According to Iranian Bundahišn:

- "war ì Sōwar pad Abar-šahr būm pad sar ī kōf ì Tōs. čiyōn gōwèd kū sūd bahr ud hu-čašmīh ud wehīh abzāyišnīgīh ud rādīh aziš be dād ēstēd" (Pakzad 1384AH/2005: 164).

- "Sōwar Lake is placed in Abar-šahr at the top of Tus Mountain; it is thought that benefit, good heartedness, plenteousness and truth are created from it" (Bahar 1390AH/2011: 77).

\footnotetext{
${ }_{18}$ Avestan equivalents zarənumant, zaranumant- (Bartolomae 1904: col.1683).

${ }^{19}$ Derived from Avestan root zar- "to grow old" (Bartolomae 1904: col.1669).

${ }^{20}$ In Avesta only Sadwēs star is mentioned, not the lake (Cereti 2007: 55). Avestan form for the star is satauuaēsa(masculine noun) (Bartolomae 1904: col.1556). In Pahlavi scripts a lake is also mentioned as Sadwēs.

${ }^{21}$ Aras River, which is a source, comes out of Asnavand Mountain and runs to Dititi (Rashedmohassel 1385AH/2006: 143). According to another idea, Sadwēs Lake is a blue shallow lake covered with fog, whose place is on the top of a mountain said to be Hara (Meyers-O’Conner 1983AH/2004: 630).

${ }^{22}$ A number, Sanskrit equivalent śatá- (Mayrhofer 1996: 606), Avestan sata- (Bartolomae 1904: col.1555), Sogdian st(sat) (Gharib 1383AH/2004: 362), Ashkanid Pahlavi sd [sad] (Boyce 1977: 81), Middle Persian sad (Mackenzie 1388AH/2009: 132), and Modern Persian sad (Mo'in 1375AH/1996, vol.2: 2135).

${ }^{23}$ The name of this lake is not mentioned in Avesta (Cereti 2007: 56).
} 
Sōwar $\rightarrow$ a proper noun, probably composed of two parts: Sō + war

The original form of this word might be sūd + bahr.

sūd ${ }^{24}$ : a noun, derived from Old Iranian form sūta- "advantage, benefit" (Bailey 1979: 429), Sogdian swt (sūt) (Gharib 1383AH/2004: 366). Pazand sūd (Nyberg 1974: 181). Ashkanid Pahlavi swd (sūd) "benefit, bounty" (Boyce 1977: 83). Middle Persian sūd (Mackenzie 1388AH/2009: 139).Modern Persian sūd (Mi'on 1375AH/1996, vol.2: 1946).

bahr ${ }^{25}$ : a noun, Pazand equivalent bahar "part, portion" (Nyberg 1974: 43).Ashkanid Pahlavi bhr (bahr) (Boyce 1977; 27), Middle Persian bahr (Mackenzie 1388AH/2006: 49), and Modern Persian bahr (Mo'in 1375AH/1996, vol.1: 611).Totally, name of this lake bears concept of "beneficent".

3.9 Frazdān ${ }^{26}$ Lake

This lake is situated in Sistan and apparently equals Hāmun Lake (Cereti 2007: 56). Its feature is that if an abstinent free-man drops something into it, the lake accepts it; otherwise the lake would throw it out (Oshidari 1389AH/2010: 367). It is narrated in Zand-i Vohuman Yasn that Hūshidar will be born beside Frazdān Lake. As stated in Pahlavi scripts, when Salm and Tūr murdered Iraj, Fereydūn took Iraj’s born daughter to the lake, nurtured and trained her secretly till Manūchehr was born (Christensen 1377AH/1998: 511).

According to Iranian Bundahišn:

- "war ì Frazdān pad Sagestān. gōwēnd kū āzād mard-ēe(w) ahlaw kē tis-ēe(w) andar awiš abganēd padīrēe ka nē ahlaw abāz ō bērōn abganēd" (Pakzad 1384AH/2005: 77).

- "Frazdān Lake is located in Sistan, it is said if a well-doer man throw something in it, the lake accepts it; in the case the man is not an abstinent free-man the lake give the thing back" (Bahar 1390AH/2011: 77).

Frazdān $\rightarrow$ a proper noun, Avestan equivalent Frazdānu- (masculine noun) (Bartholomae 1904: col.1005), perhaps entered Middle Persian as $\mathrm{fra}^{27}-+$ zdā-+ nu-.

Zdā- : probably is a reduplicated stem, derived from Old Iranian dadā- ; from Old Iranian dā- "to put/create" (Bailey 1979, p.156). Sanskrit root dhā- (Mayrhofer 1996: 786), derived from Indo-European root dhē- (Pokorny 2007: 733).Old Persian root dā- "to put/throw" (Kent 1953: 188). Avestan root dā- "to create" (Bartholomae 1904: col.727).

nu-: a noun suffix, the same form as its Sanskrit equivalent (Jackson 1968: 223). The author believes that based on mythical features and aforementioned ideas, concept of the name of this lake is perhaps "to throw (something) forward".

\section{Conclusion}

The position of mythical lakes mentioned in Bundahišn, in the most central point of Iranian mythical world is $\mathrm{X}^{\mathrm{v}}$ aniras. Lots of these lakes are situated at south and adjacent to Farāxkard Sea that occupies one third of this earth. Therefore, it is logical to imagine this vast sea occupies some parts of the south of $\mathrm{X}^{\mathrm{v}}$ aniras, and from this sea all the seas, lakes and rivers originate that flow to it after running all around the world. Within this vast sea, there exist one thousand seas called "seas" sources". According to Bundahišn there are a few sources (springs) named "lake" too, these sources look like "man's eyes" because they are sources of water as well. Each of these sea-sources or lakes hold a particular name based on their features and this could be considered by means of a descriptive and an etymological study, for instance Xwārazm Lake is placed at a low height region and this matter is obvious by its name; in addition, Sōwar Lake is beneficent and bountiful in accordance with its name. Possibly, one had better not equate mythical geography of these lakes with their natural geography as the world of myth owns a completely different geography, and a geography which is mixed with myths is not the same as the natural one. Nevertheless, this research is an attempt to find the possible location of these lakes in our real world by means of comparing and contrasting Pahlavi and mythical scripts. Although in reports earned from these sources some paradoxes are always detected, presented evidences and offered etymological and mythical descriptions to some extant may help us estimate the orientation of these lakes in the real world by approximation. Moreover, etymological approach to the names of mythical lakes reveals reasons and importance of their naming process. For the reason that it seems myths and region-specific features play an important role in naming process of geographical places, and this fact is observable significantly about names of mythical lakes.

\footnotetext{
${ }^{24}$ Derived from Old Iranian saw-/su- "beneficial” (Bailey 1979: 429), Sanskrit root sav- (Mayrhofer 1996: 623), Avestan root sū- "to be beneficial" (Bartolomae 1904: col.1561).

${ }^{25}$ Derived from Old Iranian root bag- "to part" (Mansoori 1384AH/2005: 86); Avestan root bag- (Bartolomae 1904: col.921).

${ }^{26}$ Some compare it with "Gowd-i Zarreh" and say it is originating from Farāxkard Sea (Cereti 2007: 56). Yousti believes this lake is "Ab-i Istade" that can be found at the south of Ghaznī in Sistan (Max Muller 1880: 86). Bartolomae says Justi is wrong and this lake is a river in Armenia called Hrazdān (Bartolomae 1904: col.1005), and is the center of Kotayk Province and a river holding the same name passes through the city (Hewsen 1987: 150). On the other hand, Bartolome equates this lake with the Avestan lake Frada $\theta \bar{a}$ (Bartolomae 1904: col.1005), some claim this is farāh-rud at south west of Afghanistan (Balland 1999: 237). Before this lake, Kai Goštasp makes some vows and wishes to defeat his enemies (Russell 1985: 450).

27 An adverb, or verb prefix in Avestan language (ibid. 974), and its Sanskrit equivalent is prā- "afore, front" (Mayrhofer 1996: 173).
} 


\section{References}

Abolqasemi, M. (1377AH/1988). Dastour-e tarikhi-e zaban-e farsi. [A historical grammar of Persian language]. Tehran: Samt.

Afifi, R. (1374AH/1995). Asatir o farhang-e Iran. [Mythology and culture of Iran]. Tehran: Tus

Amouzegar, J. (1388AH/2009). "Darya-ye Pars az dirbaz". Farhang o Honar. [Culture \& Art]. No. 70, 115-121.

........... \& Tafazzoli, A. (1387AH/2008). Zaban-e Pahlavi, Adabiat va dastour-e an. [Pahlavi language, his literature \& grammar]. Tehran: Mo'in.

Bagha'i, N. (1375AH/1996). "Siraf, Shilav". Zaban o Adabiyat-e Farsi. [Persian language \& literature]. No. 6, 105109.

Bahar, M. (1374AH/1995). “Tishtar, Fereshteh por-shkouh-e baran-avar”. Farhang o Honar. [Culture \& Art]. No. 67, 53-56.

(1387AH/2008). Pazhouheshi dar asatir-e Iran. [A Study of Iranian myths]. Tehran: Agah. (1390AH/2011). Bundahesh. Tehran: Tus.

Bailey, H. W. (1979). Dictionary of Khotan Saka. Cambridge: Cambridge University Press.

Balland, D. (1999)."Farāhrūd", Encyclopaedia Iranica, Vol. IX, New York: Bibliotheca Persica Press, 237.

Bartholomae, Chr. (1904). Altiranisches wörterbuch. Strassburg: Verlag von Karl J. Trübner.

Behzadi, R. (1368AH/1989). Bondahesh-e hendi. Tehran: Mo'asese Motale'at va Tahqiqat-e Farhangi.

Benveniste, E. (1933). "L’Ērān-vej et l'origine legendaire des Iraniens", BSOAS 7, London: University of London., 269274.

Boyce, M. (1977). A word-list of Manichean Persian and Parthian. Leiden: Brill.

(1983AH/2004). “Ādur Gušnasp”, Encyclopaedia Iranica, Vol. I, Fasc. 5, London, Boston \& Henley:Routledge \& Kegan Paul, 475-476.

.......... (2000)."Ganzak", Encyclopaedia Iranica, Vol. X, Fasc.3, New York: Bibliotheca Persica Press, 289-290.

Brunner, C. J. (1986). "Arang", Encyclopaedia Iranica, Vol. II, Fasc. 3, London, Boston \& Henley: Routledge \& Kegan Paul, 262-263.

Cereti, C. G. (2007). "Middle Persian geographic literature II: Chapters X \& XII of the Bundahishn", Des Indo-Grecs aux Sassanides: données pour l'histoire et la géographie historique, Rome: ISIAO, Università di Roma, 55-64.

Cheung, J. (2007). Etymological dictionary of the Iranian verb. Leiden-Boston: Leiden Indo-European Etymological Dictionary Series, Brill.

Christensen, A. (1377AH/1998). Nemuneye nakhostin ensan va nakhostin shahriyar dar tarikh-e afsanei-e Iranian. [In the case of the first man \& the first king in the Iranians legendary history]. Trans. By Zh. Amouzegar \& A. Tafazzoli. Tehran: Cheshmeh.

Daryaee, T. (1388AH/2009). Shahrestanhay-e Iran-shahr. [Iranian cities]. Tehran: Tus.

Farahvashi, B. (1358AH/1979). Farhang-e zaban-e Pahlavi. [A dictionary of Pahlavi language]. Tehran: Daneshgah-e Tehran.

Gharashi, A. (1380AH/2001). Ab o kuh dar asatir-e hend-o-Irani. [Water \& mountain in Indo-Iranian mythology]. Tehran: Hermes.

Gnoli, G. (1987). "Avestan geography", Encyclopaedia Iranica, Vol. III, Fasc. 1, London \& New York: Routledge \& Kegan Paul, 44-47.

-. (1993). "Dāityā, Vạhvī", Encyclopaedia Iranica, Vol. VI, Fasc. 6, California: Mazda Publishers, 598-59

(2003). "Hāmun in literature and mythology", Encyclopaedia Iranica, Vol. XI, Fasc. 6, New York: Columbia University, 646-648.

Hasandoust, M. (1383AH/2004). Farhang-e risheh-shenakhti-e zaban-e farsi. [An etymological dictionary of Persian language]. Tehran: Farhangestan-e Zaban o Adab-e Farsi \& Asar.

(1389AH/2010). Farhang-e tatbiqi-mozou'i-e zaban-haa va gouyesh-hay-e Irani-e no. [A comparative-thematic dictionary of the new Iranian languages and dialects]. Tehran: Farhangestan-e Zaban o Adab-e Farsi \& Asar.

Henning, W. B. (1947). "Two Manichaean magical texts", BSOAS 12, London: University of London., 52- 66.

Hewsen, R. H. (1987)."Ayrarat", Encyclopaedia Iranica, Vol. III, Fasc. 2, London \& New York: Routledge \& Kegan Paul, 150-151.

Hinnels, J. (1371AH/1992). Shenakht-e asatir-e Iran. [Persian mythology]. Tr. By J. Amouzegar \& A. Tafazzoli. Tehran: Cheshmeh.

Houtsma, M. TH. (1993). First encyclopedia of Islam. 9 Volume set. Leiden: E.J. Brill. 
Humbach, H. (1998). Zamyād yasht. Wiesbaden: Harrassowitz.

Jackson, W.A.V. (1968). An Avesta grammar in comparison with Sanskrit. Stuttgart. New York City: W. Kohlhammer.

Kent, R.G. (1953). Old Persian: Grammer, texts, lexicon. New Haven: American Oriental Society.

Khalaf-e Tabrizi, M. H. (1361AH/1982). Borhan-e Qate'. Tehran: Amir-Kabir.

Khosrobeigi, H. (1368AH/1989). "Joghrafiyay-e tarikhi-e Kharazm". Pazhouhesh-haye Tarikhi. [Historical Research]. No.1, 69-94.

Kiepert, H. \& MacMillan, G.A. (1881). A manual of ancient geography. London: MacMillan and co.

Le Strange, G. (1905). The lands of the eastern caliphate: Mesopotamia, Persia and Central Asia from the moslem conquest to the time of Timur. Cambridge: University Press.

Mackenzie, D. N. (1388AH/2009). Farhang-e kouchak-e zaban-e Pahlavi. [A concise Pahlavi dictionary]. Tr. By M. Mirfakhra'i. Tehran: Pazhouheshgah-e Oloum-e Ensani va Motale'at-e Farhangi.

Mansouri, Y. (1384AH/2005). Barrasi-e risheh-shenakhti-e fe'l-hay-e zaban-e Pahlavi. Tehran: Farhangestan-e Zaban o Adab-e Farsi \& Asar.

Marquart, J. (1947). Wehrot und Arang, ed. H. H. Schaeder, Leiden: Brill.

Max Müller, F. (1880). Pahlavi texts. Part I: The sacred books of the east. Translated by E.W. West. http://www.kessinger.net

Mayrhofer, M. (1992-1996). Etymologisches wörterbuch des altindoarischen. Heidelberg: Carlwinter.

Meyers, C. L. \& O'conner, M. (1983). The word of the lord shall go forth. Philadelphia, Pennsylvania: American Schools of Oriental Research.

Mirfakhra'i, M. (1366AH/1987). Afarinesh dar adiyan. [The creation among the religions]. Tehran: Mo'asseseh Motale'at va Tahqiqat-e Farhangi.

Modi, J. (1889). "The river Karun", Asiatic Papers. Bombay: Education Society's Press, 1-22.

Mo'in, M. (1375AH/1996). Farhang-e farsi. [Persian dictionary]. Tehran: Amir-Kabir.

Mokhtari, M. (1379AH/2000). Ostourey-e Zal. [The myth of Zal]. Tehran: Tus.

Nyberg, H. S. (1974). A manual of Pahlavi, Part I: Texts; Part II: Glossary. Wiesbaden: Harrassowitz.

Oshidari, J. (1389AH/2010). Daneshnameh mazdyasna. [The encyclopedia of mazdayasna]. Tehran: Markaz.

Pakzad, F. (1384AH/2005). Bondahesh. Tehran: Markaz-e Da'eratol-Maaref-e Bozorg-e Eslami.

Planhol, X. D. (1990). "Caspian Sea geography", Encyclopaedia Iranica, Vol. V, Fasc. 1, New York: Columbia University, 48-61.

Pokorny, J. (2007). Proto-Indo-European etymological dictionary: Indogermanisches etymologisches wörterbuch. http://dnghu.org.

Pourdavoud, E. (1377AH/1998). Yasht-ha. Vol. 1. Tehran: Asatir.

Qarib, B. (1383AH/2004). Farhang-e Sogdi. [Sogdian dictionary]. Tehran: Farhangan.

Qolizadeh, Kh. (1387AH/2008). Farhang-e asatir-e Irani bar paye-e motoun-e Pahlavi. [The dictionary of Iranian myth, Based on Pahlavi texts]. Tehran: Parse.

Panaino, A. (2013). "Kayansih", Encyclopaedia Iranica, Vol. XVI, Fasc. 2, www.iranicaonline.org/articles/kayansih, 174-176.

Rapoport, Y. A. (1991). "Chorasmia in archeology and pre-Islamic history", Encyclopaedia Iranica, Vol. V, Fasc. 5. California: Mazda Publishers, 511-516.

Rashedmohasel, M. T. (1385AH/2006). Vizidegihay-e Zadasparam. Tehran: Pazhouheshgah-e Oloum-e Ensani va Motale'at-e Farhangi.

Razi, H. (1385AH/2006). Vandidad. Tehran: Behjat.

Reichelt, H. (1911). Avesta reader: Texts, notes, glossary and index. Berlin: Walter De Gruyter \& Co.

Russell, J. R. (1985). "Armeno-Iranica", Acta Iranica Encyclopédie Permanente des études Iraniennes, Vol. XI, Belgium: centre International d' Études Indo-iraniennes, 458 - 447.

Salem, A. R. (1383AH/2004). "Neyshabour va atash-e ahourai". Ketab-e Mah-e Honar. [Monthly book of art]. No. 75$76,146-152$.

Sarkarati, B. (1378AH/1999). "Bonyan-e asatiri-e hemasey-e melli-e Iran". Sayeha-ye Skekar-shodeh. [Hunted shadows]. Tehran: Cheshmeh.

Sarkhosh Curtis, V. \& Stewart S. (2005). Birth of the Persian Empire: the idea of Iran. Volume I, London: I. B. Tauris. Schmitt, R. (1990). "Black Sea", Encyclopaedia Iranica, Vol. IV, Fasc. 3, London \& New York: Routledge \& Kegan Paul, 310- 313. 
Spuler, B. (1986). "Aral Sea", Encyclopaedia Iranica, Vol. II, Fasc. 3, London, Boston \& Henley: Routledge \& Kegan Paul, 250.

Tafazzoli, A. (1990). "Cecast", Encyclopaedia Iranica, Vol. V, Fasc.1, California: Mazda Publishers, pp. 107-108.

............ (2001). "Frāxkard", Encyclopaedia Iranica, Vol. X, Fasc. 2, New York: Columbia University, 201.

............. (2006/1385 Sh). Minouy-e khrad. Tehran: Tus.

............ (2007/1386 Sh). Tarikh-e adabiyat-e Iran-e pish az eslam. [The history of Iranian pre-Islamic literature]. Tehran: Sokhan.

Vaheddoust, M. (1379AH/2000). Nahadinehay-e asatiri dar Shah-nameh-e Ferdowsi. [The mythological symbols in Shahnameh of Ferdowsi]. Tehran: Soroush.

Whitehouse, D. (1970). "Siraf: A medieval port on the Persian Gulf", World Archaeology, Vol. 2, No.2, Urban Archaeology, 141-158. 